\title{
Museological school as a process of professional formation based on traditions and innovations: Crimean foreshortening
}

\author{
Irina Chuvilova
}

\author{
Irina Valentinovna Chuvilova, $\mathrm{PhD}$ (History) \\ Head of the Research Group "Russian Museum Encyclopedia" \\ (New Institute for Cultural Research), \\ Vasilievskaya str., 13-1, 123056 Moscow \\ Russian Federation \\ e-mail: ivl12@yandex.ru
}

Muzeológia a kultúrne dedičstvo, 2020, 8:4:49-57

DOI: $10.46284 / \mathrm{mkd} .2020 .8 .4 .4$

\begin{abstract}
Museological school as a process of professional formation based on traditions and innovations: Crimean foreshortening

In this article, we describe the activities of the "Museum Studio", which opened in Koktebel in 2016. The history of Russian museology and international experience are two important pillars on which the School is based. Today, the School is a platform for educational events and discussions with the participation of leading Russian and foreign experts. The platform has developed an innovative model of interaction with specialists seeking to improve their qualification level. The main ideas and formats of this model are covered in this article.
\end{abstract}

Keywords: museology, museum history, mid-career education, inter-museum cooperation.

The creation of the Crimean Museological School's "Museum Studio" was a vital event in the Russian museum world in the 2010s. The idea to open a museological school as a scientific, educational and discussion platform for museum specialists came to the experts from the "Russian Museum Encyclopedia" research group (New Institute for Cultural Research). The grand opening and the first session of the "Museum Studio" took place on May 27-29, 2016, in Koktebel (Republic of Crimea).

Why Crimea, and why Koktebel? The history of Russian museology, taking into account its wide sociocultural and geographical background, is deeply linked to the discovery and study of archaeological sites of the peninsula. The interest in the national history gave rise to significant museum projects in Russia and coincided with the discovery of the ancient heritage of Crimea. The wish to preserve Black Sea antiquities led to the creation of a number of private and museum collections.

Among the eminent Crimean museum scientists and organizers are Ivan Stempkovsky, Christian von Steven, Semen Bronevsky, and others. Without these people and the museums they created in Crimea, the national history of museums would be incomplete and deprived of its intellectual grace. Ivan Stempkovsky, an archaeologist, collector, member of scientific expeditions in Crimea, and, finally, the mayor of Kerch, wrote in 1823 about the need to "use all available means to amass works of art and preserve them in museums, study ruins and tombs, try to save the remains of ancient buildings from complete destruction."1 Stempkovsky

${ }^{1}$ STEMPKOVSKIJ, Ivan. My'sli otnositel'no izyskaniya drevnostej v Novorossijskom krae [Thoughts on the search for antiquities in Novorossiysk region]. In: Otechestvennye zapiski. СПб, 1827, ch. 29, kn. 1, p. 62. [In Russian]. 
proposed to conduct a systematic research of historical objects covering a wide territory and including different types of objects, and also to classify and describe the findings. These proposals led to the idea of creating museums to carry out extensive scientific and collection activities.

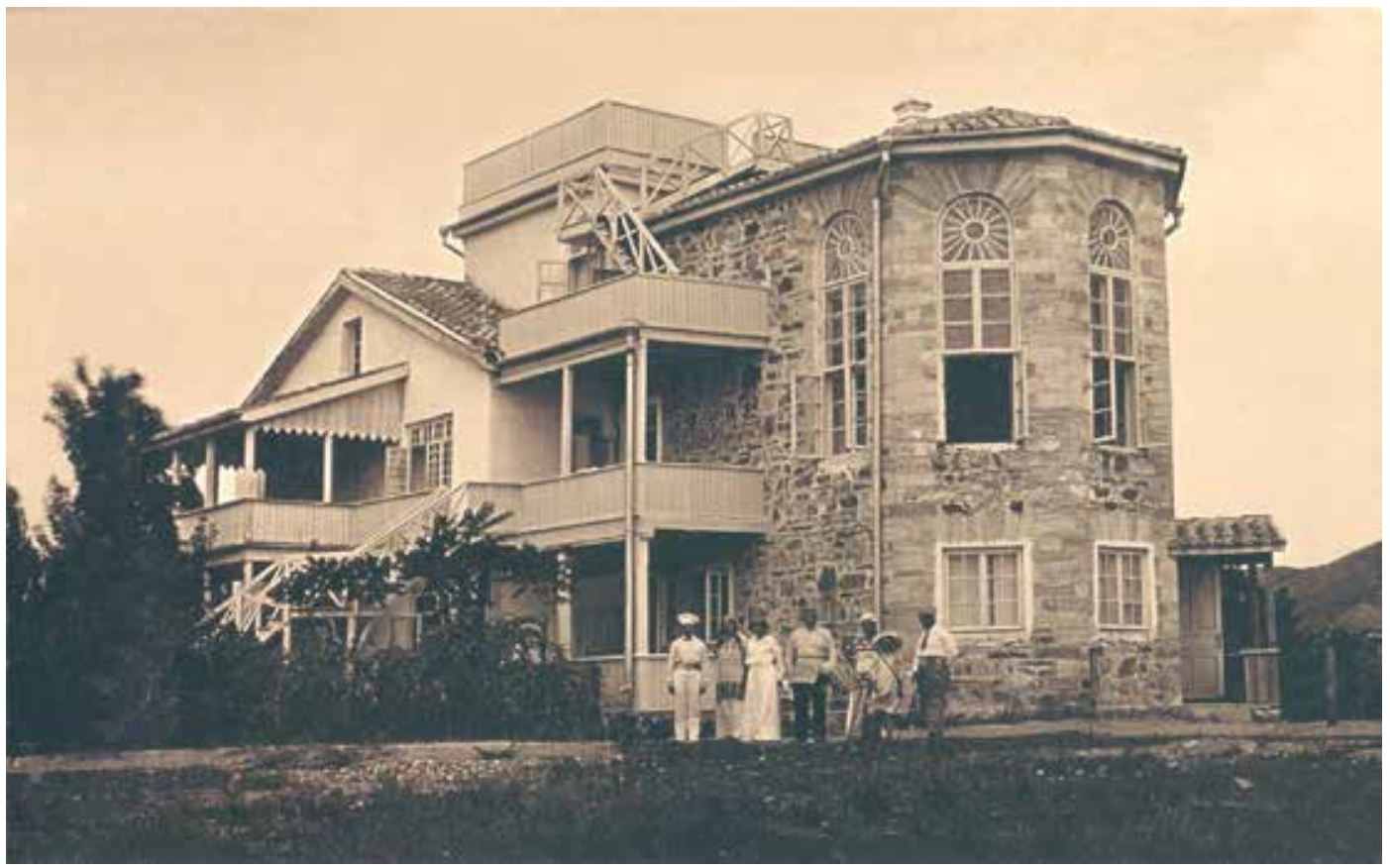

Figure 1: Maximilian Voloshin's House in Koktebel, 1916

The first government-funded network of regional historical museums open to public was created in Crimea and its adjacent areas in the south of Russia in the first three decades of the 1800s. This network included the Museum in Nikolaev (1803), Feodosia Museum of Antiquities (1811), the Museum at Simferopol Men's Gymnasium (1812), Odessa Museum of Antiquities (1825) and Kerch Museum of Antiquities (1826). One of the first museum institutions was Nikitsky Botanical Garden near Yalta: the project was drawn up in 1813 by Christian von Steven and was based on the innovative idea to create a large botanical scientific collection. In 1869, the country's first military historical museum was opened in Sevastopol. In 1880, Aivazovsky Gallery, the first public museum of fine arts in the south of Russia was opened in Feodosia. In the early twentieth century, a cultural center of world significance - Voloshin House of the Poet $^{2}$ - was opened in Koktebel. On this occasion, the poet Andrej Belyi wrote: "It is not a house but a museum, and this museum is unique." (Figure 1).

Today, Crimea's museum network includes approximately 50 government and municipal museums and is rapidly developing. Eight museum reserves play a leading role, including collections of over 200 objects of cultural heritage, such as Neolithic sites, ancient and early medieval settlements, kurgans and grave fields, Scythian and Roman hillforts, ancient hillforts, settlements, burial vaults, and necropolises related to the history of the Bosporan Kingdom.

\footnotetext{
${ }^{2}$ The House of the Poet in Koktebel is where the painter and poet Maximilian Voloshin created an art camp for writers and painters; his collected works of art and books is also preserved there.

${ }^{3}$ BELYI, Andrej. Dom-muzej M.A. Voloshina. [The House-Museum of M. A. Voloshin]. In: Zvezda. 1977, No. 5, p. 188. [In Russian].
} 
Palace and Park complexes in Alupka and Livadia are among the most outstanding museum reserves in Crimea. ${ }^{4}$

Crimean cave towns and fortresses are also being gradually turned into museums, and archeological parks are being created. Cultural heritage and museums are an important resource not only for the cultural, but also for the socio-economic development of the region. If this positive trend continues, it will be possible to talk about creating a special historical and cultural territory and develop an economic program to use the cultural heritage. This line of Crimea development seems logical and quite promising.

The museological aspects of the School's work are inspired by the best traditions of museum development in the twentieth century. Crimea has also played an important role in this development. It was precisely in Koktebel, during the difficult post-revolutionary years, that the painter and poet Maximilian Voloshin pondered the best way to organize the educational system and creative institutions of the newborn country. "The goal is that not a single person remains a stranger to the joy of artistic creation," ${ }^{5}$ he wrote in support of his 1920 s projects, which included the creation of the Public Art School, the Public Literary School, the Free Art Studios, and the Museum of Cimmerian Art. The most successful project was the creation of free summer studios for poets, writers and painters (Koktebel Art Studio). The project was supported by the government and lasted until the end of the twentieth century. As Voloshin wrote:

The coasts of Crimea have always been the focus of artistic and literary life of Russia. In summer, such Cimmerian areas as Sudak, Otuzi, and Koktebel became real art centers that gave tone and color to the whole life of the region and, moreover, had been true laboratories of creativity. ${ }^{6}$

Voloshin's idea of creating an Experimental Scientific and Artistic Studio in Koktebel is of particular importance to our project, the Crimean Museological School. According to Voloshin, the goal of the Studio was to "bridge the gap between the scientist and the painter." He added that scientists and art theoreticians would give lectures, and the Studio must publish works. ${ }^{7}$ The ideas on which the Crimean Museological School is based (the main idea being to "bridge the gap" between museum theory and practice) clearly overlaps with the ideas of Voloshin's Studio.

For a period of 80 years, the Russian Institute of Cultural Research in Moscow was in charge of the protection and actualization of heritage by means of museums. Analysis of

\footnotetext{
${ }^{4}$ ZUBAREV, A.V. Muzejnaya set' Respubliki Krym na sovremennom e'tape razvitiya [Crimean museum network at its current stage of development]. In: Murejny'e tetradi Kry'mskoj muzeologicheskoj shkoly': Metodologicheskie, metodicheskie i informatsionno-spravochny'e materialy'. Otv. red. N.M. Miroshnichenko, I.V. Chuvilova. Koktebel'-Simferopol'. No. 1, 2016, p. 60-61. [In Russian].

${ }^{5}$ VOLOSHIN, Maksimilian. Zapiska o napravlenii narodnoj xudozhestvennoj shkoly' [Note on the work of the Folk art school]. In: VOLOSHIN, Maksimilian. Sobranie sochineniy, t. 6, kn. 2. Proza 1900-1927. Ocherki, stat'i, lekcii, recenzii, nabroski, plany'. Pod red. V.P. Kupchenko, A.V. Lavrova. Moskva, 2008, p. 510. [In Russian].

${ }^{6}$ VOLOSHIN, Maksimilian. Proekt ob uchrezhdenii besplatny'x kolonij dlya poe'tov, pisatelej I xudozhnikov [Project on the creation of free summer art camps for poets, writers and painters]. In: VOLOSHIN, Maksimilian. Sobranie sochineniy, t. 6, kn. 2. Proza 1900-1927. Ocherki, stat'i, lekcii, recenzii, nabroski, plany'. Pod red. V.P. Kupchenko, A.V. Lavrova. Moskva, 2008, p. 517. [In Russian].

${ }^{7}$ VOLOSHIN, Maksimilian. Zadachi E’ksperimental'noj nauchnoj i xudozhestvennoj studii v Koktebele [Tasks of the Experimental Science and Art studio in Koktebel]. In: VOLOSHIN, Maksimilian. Sobranie sochineniy, t. 6, kn. 2. Proza 1900-1927. Ocherki, stat'i, lekcii, recenzii, nabroski, plany'. Pod red. V.P. Kupchenko, A.V. Lavrova. Moskva, 2008, p. 518. [In Russian].
} 
the Institute's activities was the focus of our reflections about the future of our School. The Institute was founded in 1932 by the Government of the Russian Soviet Federative Socialist Republic (RSFSR) as the Central Scientific Research Institute of Methods of Local History (from 1937 it was known as the Scientific Research Institute of Local History and Museum Work). During its entire existence, the Institute was a scientific and methodological center for the country's museums. ${ }^{8}$ It conducted museum research, developed methodological guidelines and recommendations, established strategies and concepts for developing museums and the country's museum network, and published the first Russian textbook on museology, as well as museum dictionaries and the "Russian Museum Encyclopedia". The Institute also trained scientific personnel for museums. From 1952 to 1972, one of the founders of the International Committee for Museology (ICOFOM), Awraam M. Razgon, a pioneer of Russian museology and museum education, worked in the Institute, where he wrote a significant portion of his works on museums.

In 1984, Awraam M. Razgon raised the idea of creating a Department of Museology in the Academy of Retraining in Culture, Art and Tourism (Moscow). The idea was to provide theoretical training to museum specialists. Collaboration between museum theorists and practitioners in a museum school is also practiced abroad. The most famous is probably the International Museum School in Brno (Czech Republic), opened in 1986 on the initiative of museologist Zbynek Z. Stransky. To some extent, the School in Brno served as a model for our School.

It is symbolical that the 1980s edition of Museum Working Papers, in which articles of leading museum theorists were published, also contains important ideas of Stransky and Razgon on the theme "Museology science or just practical museum work?" The question remains as to whether museum science is needed for the development of museum practice, and how these directions affect one another. However, the answer is still not as obvious as it should be for all museum specialists. In his short article, Razgon emphasizes that "museology studies the objects of reality - primary sources, objects of interest also of other branches, however, it has its special view in these objects and this fact demarcates the sphere of museology among other sciences" (emphasis by I. Ch.). In the same edition, Stransky writes: that "the term museology or museum theory covers an area of a specific field of study focused on the phenomenon of the museum. We face here the relation of theory and practice" (emphasis by I. Ch.). ${ }^{10}$

Today we are witnessing changes in the museum sphere. Quite revealingly, this is manifested, among other changes, in a search for new terms and revision of not only the notion of the "museum", but also of its "phenomenon". In 1980, Stransky wrote about similar processes: "The recent manifestation of the crisis in the position of the museum reflected the contradictions between the requirements of the development of society, and the stage museums have reached."11

\footnotetext{
${ }^{8}$ In 2014, it was replaced by the New Institute for Cultural Research, an independent nonprofit organization for the development of research and projects in the field of culture and art. The museum component of the New Institute for Cultural Research is the Russian Museum Encyclopedia research group.

${ }^{9}$ RAZGON, Awraam M. Museological provocations 1979 by the Editorial Board. In: MuWoP. Museological Working Papers. A debate journal on fundamental museological problems. Stockholm, Sweden, No. 1, 1980, p. 12.

${ }^{10}$ STRANSKY, Zbynek Z. Museology - science or just practical museum work? In: MuWoP. Museological Working Papers. A debate journal on fundamental museological problems. Stockholm, Sweden, No. 1, 1980, p. 44.

${ }^{11}$ Ibid., p. 44.
} 
For example, a serious problem in the country's museum sphere today is the shift from the basic directions of museum activities to management, marketing and virtual technologies. Young museum workers seem to be more involved in managerial and technological innovations, ignoring or simply having no idea about the national experience of museum practice and the basics of museology. All this negatively affects the development of the museum sphere in Russia.

Despite the complexity of these ongoing processes, the museum remains one of the most important sociocultural and scientific institutions. Moreover, its role in the life of modern society is constantly growing in relevance, making us feel the importance of theoretical reflection and analysis of practical activity, the significance of the forecasting function of science, that "special view" mentioned by Razgon. In this context, the words of his colleague Stransky are all the more relevant:

Today the problems of the museum's existence cannot be solved in the realm of practice. For the implementation of this task we need a special tool, enabling us to discover the objective sides of reality, to define its laws and to find the optimum ways of both solving daily tasks and working ahead. This task can be realized only through museum theory, moreover, through museology. ${ }^{12}$

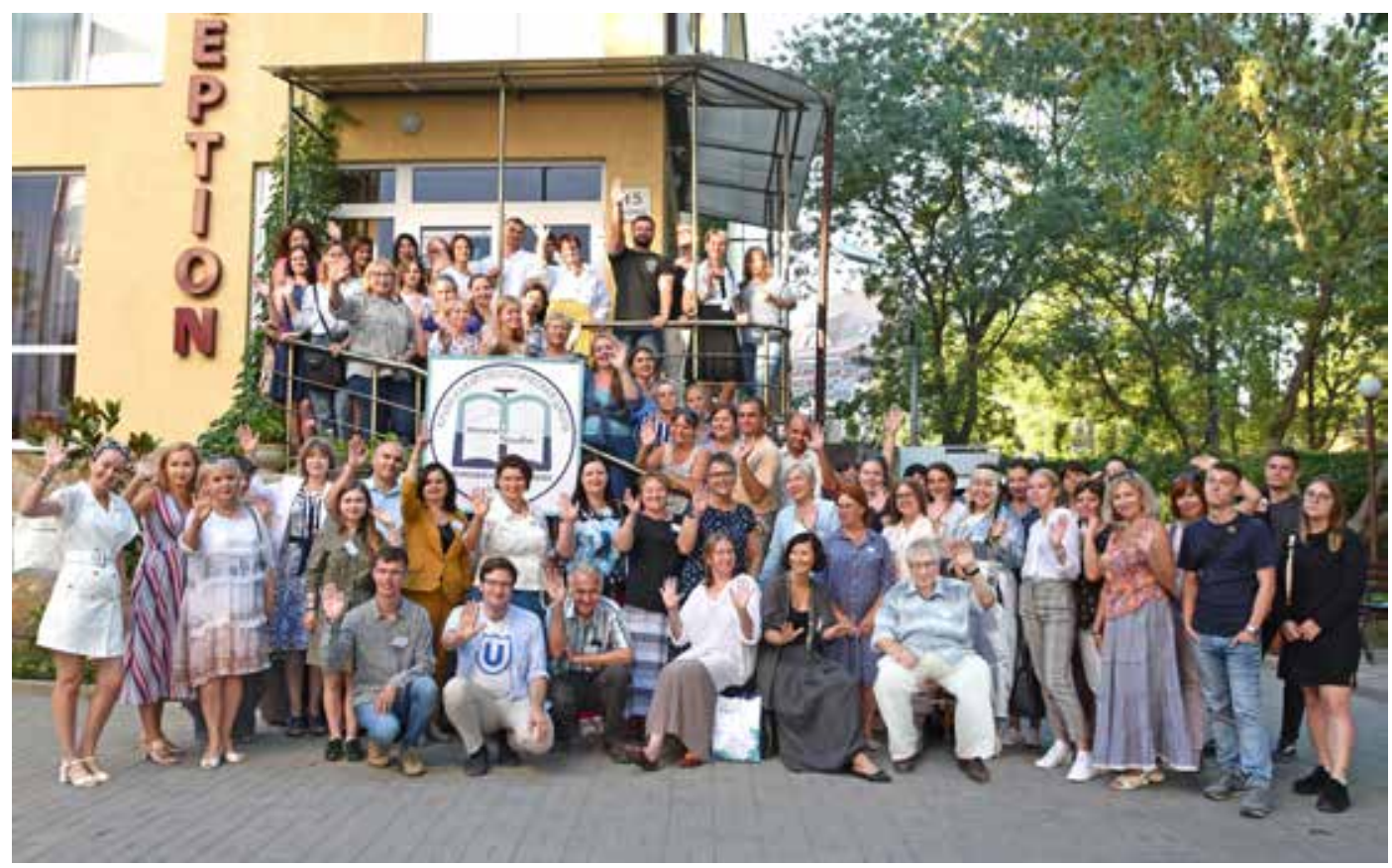

Figure 2: Fifth session of the School, 2020: students and lecturers

Therefore, one of the School objectives is to comprehend innovations and analyze modern trends in museum practice, including foreign experience, relying on the best traditions of Russian museology, as well as national and regional historical and cultural traits. It is particularly important to transfer this experience to museums in small towns and rural settlements. The idea is that museum specialists from various regions of the country will receive advanced training (mid-career education) that will, above all, include the analysis of the main directions

${ }^{12}$ Ibid. 
of museums' activities and work on mistakes. Specific goals must be set and achieved through the joint efforts of invited experts and employees of regional museums (Figure 2).

Each museum, regardless of its profile and size, gives visitors the feeling of belonging to the region's history and makes them think about the heritage that is stored there. Therefore, one of the School's objectives is to support and develop the regional identity of communities by increasing the effectiveness of museums' activities for the local population. A century ago, Voloshin expressed the idea, which is in harmony with our goals:

The main value of museum activities is not the collection of masterpieces, but an introduction to the knowledge of nature and life, as well as examples of its transformation. Museums must be local and represent the geological past of a region, its nature, historical development, folk art, folklore, and individual artistic transformations. ${ }^{13}$

Thus, key principles on which the Crimean Museological School is based are as follows:

1. The Crimean Museological School is a new educational and discussion platform for organizing and holding annual meetings of specialists to discuss vital issues related to the state and prospects of Russian museums, with the participation of leading Russian and foreign experts.

2. The creation of a museum school in Crimea is inspired by all the previous experience in developing the national museum sphere and is an innovative one-of-a-kind Russian project.

3. The Crimean Museological School is a joint project of the Voloshin Cimmeria Museum Reserve (Republic of Crimea) and the "Russian Museum Encyclopedia" research group (Moscow). The School cooperates with leading national and foreign museum centers, including the Department of Museology of the Russian State University for the Humanities (Moscow), the Research and Education Center "Civil Society and Social Communications" of the Russian Presidential Academy of National Economy and Public Administration (Moscow), the Scientific Museum Council of the Siberian Branch of the Russian Academy of Sciences (Novosibirsk), and others.

Over the last four years, we have developed an innovative model of interaction with experts willing to improve their qualification. A significant part of the program is education. Our students can receive certificates of advanced training (mid-career education). For each session, a special program is developed covering some of the topics and directions in museum activities that, in our opinion, are most in demand today: education in museums, cultural actions, exhibition studies and display, preservation of museum objects, management and marketing. The first orientation session took place in 2016 under the theme "Why do museums need museology?" and included lectures on basic museum topics, such as "Museums and heritage", "Museums in a region" and "Museums and communication". ${ }^{14}$ In fact, these topics determined the content of the School's next sessions. The classes are given by leading experts in the museum studies, conservation, and the use and management of heritage.

Practical issues also receive a lot of attention. In addition to workshops, experts from different Russian museums present their projects and studies in the format of discussions with

\footnotetext{
${ }^{13}$ VOLOSHIN, Maksimilian. Iskusstvo videt' prirodu i ponimaniya xudozhestvenny'x proizvedenij (Chem dolzhny' by't' narodny'e muzei) [The art of contemplating nature and understanding artworks (What is the purpose of a folk museum?)]. In: VOLOSHIN, Maksimilian. Sobranie sochineniy, t. 6, kn. 2. Proza 1900-1927. Ocherki, stat'i, lekciï, recenzii, nabroski, plany'. Pod red. V.P. Kupchenko, A.V. Lavrova. Moskva, 2008, p. 728. [In Russian].

${ }^{14}$ Lectures on these topics were published in the first edition of the «Museums notebooks»: Muzejny'e tetradi Kry 'mskoj muzeologicheskoj shkoly': Metodologicheskie, metodicheskie i informatsionno-spravochny'e materialy'. Otv. red. N.M. Miroshnichenko, I.V. Chuvilova. Koktebel'-Simferopol'. Vypusk 1, pp. 60-69. [In Russian].
} 
the School's students. From 2016 to 2019, the reports presented included topics such as "The revival of Voloshin's estate in Koktebel as a historical cultural center", "Strategic planning in the museum", "Museum visitor profiles", "Introduction of museum pedagogy in preschool education" and more. It has become a tradition to invite a special guest lecturer - a foreign expert in museology and heritage protection - to give an orientation lecture at the beginning of each session. This helps our students towards a deeper understanding of modern trends in the development of museum theory and practice. In 2017, 2018 and 2019, the following lectures were given by museum experts:

- Dr Jan Dolák, Assistant Professor of Ethnology and Museology from Comenius University in Bratislava (Slovakia): "The thing as an object of museum collection and presentation".

- Dr M. Cristina Vannini, Director of the museum consultancy company "SoluzioniMuseali", Trustee of the Board of European Museum Forum (EMF/EMYA) (Italy): "Communication in contemporary museums: balancing tools, contents and audiences".

- Dr Matthias Henkel, Professor of European Ethnology and Archaeology from the University of Goettingen, founder of the "Embassy of Culture" Agency (Germany): "Old exhibits, new challenges and future perspectives. Working on museums as hubs of relevance".

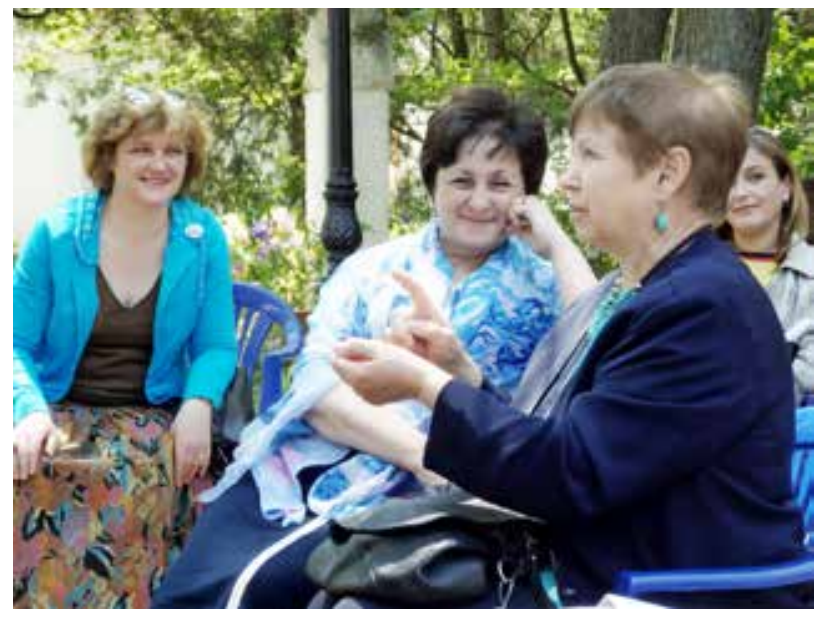

Figure 3: A lesson is conducted by Prof. Maria Kaulen

The 2020 School schedule includes a lecture by Dr Darko Babić, Chair of Museology at the Faculty of Humanities and Social Sciences, University of Zagreb (Croatia) on "21st Century Museum Management: importance of interpretation and literacy as management tools".

The School has recently adopted a new format, regularly conducting a seminar on "Preservation, musealisation, and actualization of historical and cultural heritage". The idea behind this seminar came from the scientific curator of the Crimean Museological School, the famous Russian museologist Maria Kaulen, and the unit discusses various museum heritage issues and looks for answers to difficult questions (Figure 3).

The Crimean Museological School uses a variety of work formats, including seminars, workshops, round-tables, literary evenings, film screenings and the programs "Museum Workshop" (for example, in 2019, a workshop was held called "New trends in museum design"), and "Museum Crossroads" (in 2019, experts from the Stroganov Moscow State University of Arts and Industry presented their design projects). In the course of lectures, business games and presentations, we discuss museum history, theory, and practice, sociocultural design, heritage management, and other issues. We also usually hold an event "Meet the Crimean Museums". The School's work is organized in a way that all participants are involved in close collaboration. They are free to exchange ideas and actively participate in discussions.

Our first and foremost task is to help museum specialists from different regions of the country to improve their qualifications and skills. However, we understand that the forma- 


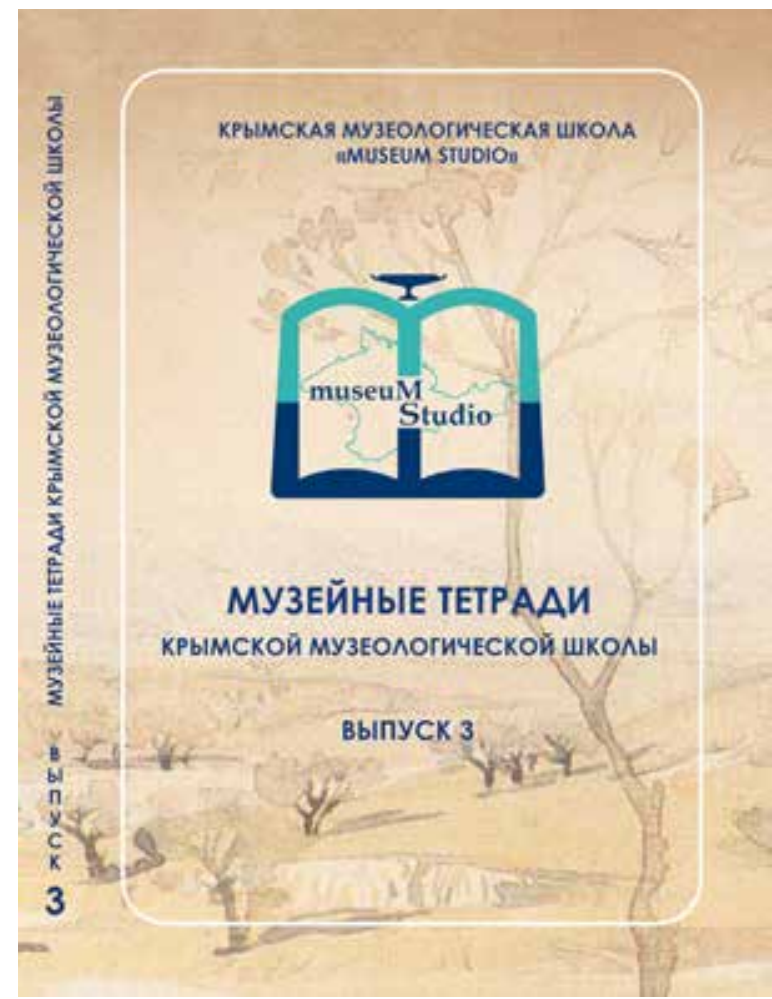

Figure 4: Cover of the "Museums notebooks" edition (issue 3, 2018)

tion of a true museum professional must start at university. Since 2017, the School has been holding a research and creative competition for student projects called "Exciting museology". Applications are collected over a period of three months from various universities (from Crimea to Siberia and Altai) with specialized museum departments. Projects are selected for the finals in which the School's students and members of the jury also participate. Currently, the competition covers are two areas "Museum projects" and "Museum research"; three prizes are awarded in each of these areas. The winners receive support in implementing their projects in museums; their reports are published in the School's publication (Museums' Notebooks) along with the lectures of museum experts. Over the three years the competition has been running, the following projects have received awards: "Ethnographic mosaic: dialogue of cultures", which focuses on the musealisation of a Simferopol city quarter; "Kökköz", a project of the Tatar eco-museum in Crimea; a research project called "The fate of the exhibition: 'Important stages in the development of Russian painting' that disappeared during the Second World War"; "Educational quest as a means of promoting ancient Russian heritage", and other projects.

As a result of each session, a new edition of Museums' Notebooks is issued including abstracts of lectures, references, notes on practical experience in museums, and student projects. Between 2016 and 2019, four editions were issued. ${ }^{15}$ We hope that future editions will continue to offer insight into the results of our work, providing a helpful resource for museum specialists (Figure 4).

The Crimean Museological School "Museum Studio" is open to all museum specialists, including those who have only recently joined our community and those who have long been committed to the common cause. Over the four years we have been operating, museum specialists from different parts of Russia, Ukraine, Belarus have joined us as students and become our friends. The goal of our meetings is not only to teach but to learn from each other, to explore and discuss, while preserving the idea of high professionalism, openness, and accessibility laid down by our predecessors.

In 2020, the project received the Grant of the President of the Russian Federation for the development of civil society awarded by the Presidential Grants Fund. It shows that the Crimean Museological School has become an important platform for professional cooperation

${ }^{15}$ Murejny'e tetradi Kry'mskoj muzeologicheskoj shkoly': Metodologicheskie, metodicheskie i informatsionno-spravochny'e materialy'. Otv. red. N.M. Miroshnichenko, I.V. Chuvilova. Koktebel'-Simferopol'. Vypusk 1-5, 2016-2020. 
and discoveries.

\section{References}

BELYI, Andrej (1977). Dom-muzej M. A. Voloshina. [The House-Museum of M. A. Voloshin]. In: Zvezda, No. 5, p. 188-190. [In Russian]. ISSN 0321-1878

RAZGON, Awraam M. Museological provocations 1979 by the Editorial Board (1980). In: MuWoP. Museological Working Papers. A debate journal on fundamental museological problems. Stockholm, Sweden, No. 1, p. 11-12. ISBN 91-7192-471-X

STRANSKY,Zbynek Z. Museology - science or just practical museum work? (1980) In: $M u W o P$. Museological Working Papers. A debate journal on fundamental museological problems. Stockholm, Sweden, No. 1, p. 42-44. ISBN 91-7192-471-X

STEMPKOVSKIJ, Ivan. My'sli otnositel'no izyskaniya drevnostej v Novorossijskom krae [Thoughts on the search for antiquities in Novorossiysk region]. In: Otechestvenny'e rapiski. СПб, ch. 29, kn. 1, p. 40-72. [In Russian].

VOLOSHIN, Maksimilian. Zapiska o napravlenii narodnoj xudozhestvennoj shkoly' [Note on the work of the Folk Art School] (2008). In: VOLOSHIN, Maksimilian. Sobranie sochineniy, t. 6, kn. 2. Proza 1900-1927. Ocherki, stat'i, lekecii, recenzii, nabroski, plany'. Pod red. V.P. Kupchenko, A. V. Lavrova. Moskva, p. 510-513. ISBN 978-5-902152-50-7

VOLOSHIN, Maksimilian. Proekt ob uchrezhdenii besplatny'x kolonij dlya poe'tov, pisatelej I xudozhnikov [Project on the creation of free summer art camps for poets, writers and painters] (2008). In: VOLOSHIN, Maksimilian. Sobranie sochineniy, t. 6, kn. 2. Proza 19001927. Ocherki, stat 'i, lekcii, recenzii, nabroski, plany'. Pod red. V. P. Kupchenko, A. V. Lavrova. Moskva. ISBN 978-5-902152-50-7

VOLOSHIN, Maksimilian. Iskusstvo videt' prirodu i ponimaniya xudozhestvenny'x proizvedenij (Chem dolzhny' by't' narodny'e muzei [The art of contemplating nature and understanding artworks (What is the purpose of a folk museum?)] (2008). In: VOLOSHIN, Maksimilian. Sobranie sochineniy, t. 6, kn. 2. Proza 1900-1927. Ocherki, stat'i, lekcii, recenzii, nabroski, plany'. Pod red. V.P. Kupchenko, A.V. Lavrova. Moskva. [In Russian]. ISBN 978-5902152-50-7

VOLOSHIN, Maksimilian. Zadachi E’ksperimental'noj nauchnoj i xudozhestvennoj studii v Koktebele [Tasks of the Experimental Science and Art studio in Koktebel] (2008). In: VOLOS HIN, Maksimilian. Sobranie sochineniy, t. 6, kn. 2. Proza 1900-1927. Ocherki, stat'i, lekcii, recenzii, nabroski, plany'. Pod red. V.P. Kupchenko, A.V. Lavrova. Moskva, p. 518-520. [In Russian]. ISBN 978-5-902152-50-7

ZUBAREV, A.V. (2016). Muzejnaya set' Respubliki Krym na sovremennom e'tape razvitiya [Crimean museum network at its current stage of development]. In: Murejny'e tetradi Kry'mskoj muzeologicheskoj shkoly': Metodologicheskie, metodicheskie i informatsionno-spravochny'e materialy'. Otv. red. N.M. Miroshnichenko, I.V. Chuvilova. Koktebel'-Simferopol'. Vypusk 1, p. 60-69. [In Russian]. ISBN 978-5-9908385-4-3 